\title{
EFFECT OF FEEDING DIFFERENT LEVELS OF CALCIUM SALTS OF FATTY ACIDS ON DIGESTIBILITY, BODY DIMENSION AND CARCASS CHARACTERISTICS OF FATTENING BUFFALO BULLS
}

\author{
F. M. Abo -Donia and S. A. Ibrahim
}

Animal Production Research Institute, Ministry of Agriculture, Dokki, Giza, Egypt

\section{SUMMARY}

Eighteen buffalo bulls were allotted into three similar groups. Three concentrate feed mixture were formulated to replace Calcium salts of fatty acids (Ca-SFA) instead of corn grain as 0, 25 and 50\% on basis of energy content then distributed to three animal groups. All groups received berseem hay and rice straw. Acid ether extract (AEE) and total fatty acids (TFA's) were higher with high level of Ca-SFA. Adding Ca-SFA significantly $(P<0.05)$ improved meat yield $\mathrm{kg}$ as level of fat intake was higher. Intake of DM, TDN and DCP $\mathrm{kg}$ per $\mathrm{kg}$ meat gain was slightly more efficient when feeding with different levels of Ca-SFA. Digestion coefficient of AEE was significantly higher $(P<0.05)$ with supplemented $C a-S F A$, while digestibilities of crude protein (CP), crude fiber (CF) and nitrogen free extract (NFE) didn't affected by fat supplemented. The values of TDN $\mathrm{kg}$ and DCP didn't significantly differ among the tested groups.

No significant $(P>0.05)$ differences were found among treatments for body dimension. Both levels of Ca-SFA didn't significantly ( $P>0.05)$ affect fasting, empty body weight and carcass weight compared to the control one. Rump round, neck and hot carcass were significantly higher $(P<0.05)$ with $50 \%$ level of Ca-SFA compared to the control one, while there was no significant difference $(P>0.05)$ between both levels of Ca-SFA. No significant differences were observed for dressing values among treatments. Amount of meat for hind and fore right and hind left quarters were significantly higher $(P<0.05)$ with feeding on $C a-S F A$. Kidney fat and liver weight were significantly higher $(P<0.05)$ when fed ration containing $C a-S F A$ than that on the control ration, except the average of liver weight for that group received ration containing 25\% Ca-SFA level. Color intensity of fresh muscle, area, depth of longissimus dorsi muscle and fat content of muscles of 9, 10, and $11^{\text {th }}$ ribs were significantly higher $(P<0.05)$ with added 25 and 50\% levels of Ca-SFA compared to the control. Chemical composition of CP, lipids, NFE and ash for longissimus dorsi muscle didn't significantly ( $P>0.05)$ affected with feeding Ca-SFA, while DM was significantly $(P<0.05)$ higher with feed Ca-SFA compared to the control. There was a preferential deposition of more unsaturated fatty acids in the subcutaneous adipose tissues in groups fed on Ca-SFA and linoleic acid. The unsaturated fatty acid content of longissimus dorsi muscle was less than that in subcutaneous adipose tissues when fed on Ca-SFA diet. The correlations found between body weight and other traits of body dimensions were higher than these correlations between Hot carcass (HC) and Abdominal girth $(A G)$, Hot carcass (HC) and Highet at withers $(H W)$, Heart girth $(H G)$ and Abdominal girth $(A G)$ also Heart girth $(H G)$ and Highet at withers $(H W)$.

Issued by The Egyptian Society of Animal Production 
It is concluded that, adding Ca-SFA in finishing period of buffalo bulls might be improved carcass quality and meat gain efficiency.

Keywords: Buffalo bulls, calcium salts of fatty acids (Ca-SFA), digestibility, body dimensions and carcass traits

\section{INTRODUCTION}

A growing phase for cattle is usually imposed for a period between weaning and finishing in a feedlot. The growing phase allows body development before fattening, which in turn permits cattle to attain slaughter finish at desirable carcass weights. Commercial feed fats, usually supplemented at 2 to $5 \%$ of the diets dry matter, for growing and finishing cattle (Bauman et al., 2003). Soap-stock as fatty acids has a higher inhibitory effect on ruminal microbes than the triglycerides form (Wu et al., 1993). The negative effects of lipids on the digestion efficiency in the rumen are generally reduced by adding calcium supplementation to the diet (Jenkins and Palmquist, 1982 and El-Bedawy et al., 2005).

In recent years awareness of the importance of diet in human health has increased. Many authorities have recommended that the contribution of fat especially saturated fatty acids to dietary energy intake should be reduced. In the UK recent recommendations were $35 \%$ of energy for fat and $10 \%$ of energy for saturated fatty acids (Henderson et al., 2003). Within these general guidelines it is advised to reduce the intake of short- and medium-chain saturated fatty acids and the intake of n-6 polyunsaturates relative to $n-3$ (Gibney, 1993).

The objective of the present work is to incorporate different levels of calcium salts of fatty acids which produced from soap-stock (SS) as source of energy in fattening buffalo bull's rations at the finishing of fattening period. The effects of CaSFA supplementation in fattening buffalo bull's would be investigated on body dimensions, carcass traits, profile of fatty acids, intake, digestibility of nutrients and performance of meat production.

\section{MATERIALS AND METHODS}

This work has been conducted at Seds experimental station in Bani-souif Governorate and chemical analyses were conducted at Laboratory of By-Product Utilization Department belongs to Animal Production Research Institute, Agricultural Research Center, Ministry of Agriculture, Egypt.

Calcium salts of fatty acids (Ca- SFA) was locally prepared in Soap \& Oil Manufacture (Cairo Oil \& Soap Co.,) according to El-Bedawy et al. (2005) from mixed of soybean and sunflower oil soapstock by 1:1 on DM basis.

Eighteen buffalo bulls about $295.0 \pm 7.31 \mathrm{~kg}$ body weight at one year of age were randomly allotted into three similar groups. Bulls were housed in three shaded paddocks and adapted on the experimental rations for two weeks before experimental period which lasted to 120 days. During the experimental period, animals were weighted biweekly. Measurements of body dimensions were made at the beginning and the end of feeding trials according to the description of (El-Kholy, 1991).

Three concentrate feed mixtures (CFM's) were formulated to replace Ca-SFA instead of corn grain as 0,25 and $50 \%$ on basis of energy content and randomly 
assumed on three animal groups. The CFM's had almost similar protein and energy content (chemical composition of different CFM's shown in Table 1). The three CFM's were randomly offered to the three animal groups. All groups received berseem hay $(\mathrm{BH})$ and rice straw $(\mathrm{RS})$. The tested rations were offered according to nutrient requirements of NRC (2000). Drinking water and minerals blocks were available all times daily.

Table 1. Chemical composition of the consumed concentrate feed mixtures, experimental rations, Ca-SFA and roughages (BH and $\mathrm{RS}$ )

\begin{tabular}{|c|c|c|c|c|c|c|c|c|c|}
\hline \multirow{2}{*}{ Item } & \multicolumn{3}{|c|}{ CFM's } & \multirow{2}{*}{$\begin{array}{c}\mathrm{Ca}- \\
\mathrm{SFA} \\
\end{array}$} & \multicolumn{2}{|c|}{ Roughages } & \multicolumn{3}{|c|}{ Experimental Rations * } \\
\hline & CFM1 & CFM2 & CFM3 & & $B H$ & $R S$ & Control & $L F L$ & HFL \\
\hline \multicolumn{10}{|c|}{ Chemical compassion $(\%)$} \\
\hline DM & 90.24 & 90.44 & 90.61 & 94.78 & 90.29 & 93.00 & 90.99 & 91.10 & 91.18 \\
\hline $\mathrm{OM}$ & 90.52 & 89.19 & 88.16 & 78.22 & 87.50 & 87.20 & 88.99 & 88.30 & 87.77 \\
\hline $\mathrm{CP}$ & 18.11 & 18.37 & 18.62 & $\ldots$ & 12.30 & 3.50 & 12.96 & 13.10 & 12.35 \\
\hline $\mathrm{CF}$ & 9.42 & 9.95 & 10.62 & & 28.50 & 40.50 & 21.78 & 22.05 & 21.80 \\
\hline $\mathrm{AEE}$ & 4.12 & 7.27 & 10.34 & 78.22 & 1.60 & 0.93 & 2.74 & 4.38 & 5.79 \\
\hline NFE & 58.87 & 53.60 & 48.58 & & 45.10 & 42.27 & 51.51 & 48.78 & 47.82 \\
\hline Ash & 9.48 & 10.81 & 11.84 & 21.78 & 12.50 & 12.80 & 11.01 & 11.70 & 12.23 \\
\hline TFA's & 3.15 & 6.10 & 8.95 & 76.96 & 0.95 & 0.47 & 2.05 & 3.59 & 5.59 \\
\hline \multicolumn{10}{|c|}{ Cell wall constituent $(\%)$} \\
\hline $\mathrm{NDF}$ & 20.08 & 20.58 & 21.31 & $\ldots$ & 62.99 & 71.89 & 43.01 & 43.25 & 43.51 \\
\hline $\mathrm{ADF}$ & 14.69 & 15.41 & 16.26 & $\ldots$ & 46.34 & 55.47 & 32.30 & 32.65 & 33.00 \\
\hline ADL & 1.61 & 1.60 & 1.61 & $\ldots$ & 7.90 & 10.37 & 5.29 & 5.28 & 5.26 \\
\hline Cell & 13.09 & 13.81 & 14.65 & $\ldots$ & 38.44 & 45.40 & 27.01 & 27.38 & 27.74 \\
\hline HCell & 5.39 & 5.17 & 5.04 & $\cdots$ & 16.65 & 16.11 & 10.72 & 10.60 & 10.51 \\
\hline $\mathrm{GE}^{* *}$ & 4.025 & 4.136 & 4.245 & 7.402 & 3.982 & 4.101 & 4.036 & 4.094 & 4.147 \\
\hline \multicolumn{10}{|c|}{$\begin{array}{l}\text { CFM1 }=\text { containing yellow corn }(40 \%) \text {, soybean meal }(14 \%) \text {, cotton seed meal }(15 \%) \text {, wheat bran }(19 \%) \text {, } \\
\text { rice bran }(4 \%) \text {, molasses }(4 \%) \text {, ground limestone }((3 \%) \text { and common salt }(1 \%) \text {. CFM2 }=25 \% \text { Ca-SFA } \\
\text { was supplemented instead yellow corn on energy basis and CFM3 }=50 \% \text { Ca-SFA was supplemented } \\
\text { instead yellow corn on energy basis. Cell= cellulose and HCell= Hemicellulose. LFL=low fat level of } \\
25 \% \mathrm{Ca}-\mathrm{SFA} \text { and } \mathbf{H F L}=\text { high fat level of } 50 \% \text { Ca-SFA } \\
{ }^{*} \text { Formulas of experimental rations were calculated from average feed consumed during experimental } \\
\text { period } \\
* * \mathrm{Mcal} / \mathrm{kg} \text { and } \mathrm{CFM} \text { 's }=\text { Concentrate feed mixture }\end{array}$} \\
\hline
\end{tabular}

Digestion trials was carried out at the end of the experimental period using three replicates applying the acid insoluble ash (AIA) technique suggested by Van Keulen and Young (1977). Chemical composition of feeds or residuals and feces were determined according to A.O.A.C. (2000). Acidified ether extract was determined as described by modified method Abo-Donia et al. (2003). Neutral detergent fiber (NDF), acid detergent fiber (ADF) and acid detergent lignin (ADL) were determined according to Goering and Van Soest (1970). Hemi-cellulose and cellulose were calculated as the difference between NDF and ADF, ADL orderly. Total fatty acids (TFA's) in Ca-SFA and different ingredients were determined by A.O.C.S. (2000). Profile of fatty acids composition of Ca-SFA in Table (3) was analyzed by description of Sukhija and Palmquist (1988).

At the end of feeding trials, randomly three animals from each experimental group were fasted $18 \mathrm{hrs}$ then slaughtered for carcass evaluation. Empty body weight (EBW) was calculated as the difference between fasted weight and gastrointestinal (GI) tract contents (Sainz et al., 1995). The $\mathrm{pH}$ value of meat tissues was measured 
by $\mathrm{pH}$ meter as described by Aitken et al. (1962). The color intensity of meat water extract and drip were determined according to the method described by Hussaini et al. (1950). Tenderness and water holding capacity were determined according to the method described by Grau and Hamm (1957). Moisture, ash, crud protein and Lipids contents were analyzed according to the methods described by (A.O.A.C., 2000). Nitrogen free extract (NFE) in meat was calculated as the following equation 100 $(\mathrm{CP}+$ Lipids + ash $)$. The 9,10 and $11^{\text {th }}$ rib sections of each carcass were separated into lean, fat and bone with each portion being weighed. The soft tissue from these sections and the longissimus dorsi muscle at the $12^{\text {th }}$ rib were subjected to proximate analysis. Three fat sample of each group from subcutaneous adipose tissues of each animal were integrated in one sample by $1: 1: 1$ as well as samples of longissimus dorsi muscle then frozen and stored at $-18{ }^{\circ} \mathrm{C}$ to be used for determining fatty acids as methyl esters by the gas-liquid chromatographic procedure of Gerhardt and Gehrke (1977). Gas liquid chromatography of the methyl esters was conducted on an $\mathrm{F}$ and M Model 402 gas liquid chromatograph with a hydrogen flame ionization detector. A U-shaped glass column, $1.8 \mathrm{~m}$ long and $3.5 \mathrm{~mm}$ in diameter, packed with $15 \%$ diethylene glycol succinate (DEGS) on 60-80 mesh Chromosorb W was used. The column oven was maintained at $180{ }^{\circ} \mathrm{C}$ isothermally. The flash heater and the detector were operated at an average temperature of $230 \mathrm{C}$ and $240{ }^{\circ} \mathrm{C}$, respectively. The hydrogen, nitrogen and air flow rates were 38,70 and $625 \mathrm{ml}$ per minute, respectively.

Statistical analysis was carried out using SAS (2000). Duncan's Multiple Range Test (Duncan, 1955) was used to separate the means when the main effect was significant.

\section{RESULTS AND DISCUSSIONS}

\section{Chemical Composition}

Chemical composition of the CFM's, experimental rations, Ca-SFA, BH and RS are presented in Table (2). It is showed that the three CFM's and rations were comparable in nutrient content except the AEE and TFA's they were higher with the high level of Ca-SFA in concentrate feed mixture or consumed rations. The content of AEE was much higher than that of ether extract, because fatty acids in Ca-SFA are incompletely extracted without acid treatment (Drackly et al., 1985 and Abo-Donia et al., 2003). As expected, total amount of total fatty acids were higher with rations containing Ca-SFA than the control and in reasonable agreement with acid ether extract analysis. The differences between values of AEE and TFA's $1.26 \%$ in CaSFA due to higher content of other lipids such glycerol, pigments, wax .etc, which almost reach to $12 \%$. These results were nearly similar to those reported by Kim et al. (1993) and Aiad et al. (2005). The chemical compositions of the roughages (BH and RS) were within the normal published ranges for $\mathrm{CP}, \mathrm{CF}$, and $\mathrm{CWC}$ (CLFF, 2001). Unsaturated fatty acids (USF) in Ca-SFA reached to 75.5 vs. 25.5 for saturated fatty acids (SFA) and were enriched in C18:1 and C18:2 (see Table 2).

Table 2. Fatty acids composition of Ca-SFA

\begin{tabular}{llllllllll}
\hline Items (\%) & C14:0 & C16:0 & C16:1 & C18:0 & C18:1 & C18:2 & C18:3 & $\sum$ UNS & $\sum$ SA \\
\hline Ca- SFA & 6.00 & 11.50 & 3.00 & 8.00 & 37.50 & 24.50 & 9.50 & 75.5 & 25.5 \\
\hline
\end{tabular}

$\sum \mathrm{UNS}=$ Unsaturated fatty acids and $\sum \mathrm{SA}=$ Saturated fatty acids. 
Feed Intake and performance of meat production

Intake of CFM's, berseem hay and rice straw $\mathrm{kg} / \mathrm{h} / \mathrm{d}$ were similar among all experimental groups (Table 3). Adding fat improved meat yield $\mathrm{kg}$ significantly $(\mathrm{P}<0.01$ and 0.05$)$ as level of fat intake was higher. There was improve in daily meat gain with increasing level of Ca-SFA in bull's rations compared to control, while differences weren't significant $(\mathrm{P}>0.01$ and 0.05$)$ among treatments. The same trained were observed for values of total dry matter intake (TDMI) $\mathrm{kg} / \mathrm{kg}$ meat gain, $\mathrm{kg}$ total digestible nutrient intake (TDNI) $/ \mathrm{kg}$ meat gain and $\mathrm{kg}$ digestible crud protein intake (DCPI) / kg meat gain among all experimental groups.

The intake of DM, TDN and DCP $\mathrm{kg}$ per $\mathrm{kg}$ meat gain were efficient when feeding different levels of Ca-SFA compared to the control ration. This could be attributed to high fat digestibility leading to increase fat efficiency as a source of energy. Improve conversion of TDN and protein intake might be due to proportion of fat deposited in the carcass as it directly related to energy intake during the finishing phase (Byers, 1982).

Table 3. Effect of feeding Ca-SFA level on FI and feed conversion of buffalo bulls

\begin{tabular}{|c|c|c|c|c|}
\hline \multirow{2}{*}{ Item } & \multicolumn{3}{|c|}{ Experimental Rations } & \multirow{2}{*}{$\pm \mathbf{S E}$} \\
\hline & Control & LFL & HFL & \\
\hline \multicolumn{5}{|c|}{ Feed intake (FI) kg/h /day on DM basis for slaughtered animals: } \\
\hline CFM's & 3.97 & 4.07 & 4.03 & --- \\
\hline Berseem hay & 1.60 & 1.63 & 1.61 & --- \\
\hline Rice straw & 2.05 & 2.10 & 2.05 & --- \\
\hline Total DM intake & 7.62 & 7.80 & 7.96 & --- \\
\hline TDN intake & 5.03 & 5.34 & 5.56 & 0.278 \\
\hline Meat yield (kg) & $177.77^{\mathrm{c}}$ & $190.33^{b}$ & $204.83^{\mathrm{a}}$ & 2.560 \\
\hline Daily increase of meat $(\mathrm{kg})$ & 0.514 & 0.564 & 0.585 & 0.032 \\
\hline \multicolumn{5}{|l|}{ Feed conversion: } \\
\hline $\mathrm{Kg}$ DMI/kg meat yield & 14.82 & 13.83 & 13.61 & 1.320 \\
\hline $\mathrm{Kg}$ TDNI $/ \mathrm{kg}$ meat yield & 9.79 & 9.47 & 9.50 & 0.889 \\
\hline $\mathrm{Kg} \mathrm{DCPI} / \mathrm{kg}$ meat yield & 1.418 & 1.328 & 1.222 & 0.126 \\
\hline
\end{tabular}

Means of 3 animals in each treatment. $\mathbf{L F L}=$ low fat level of $25 \% \mathrm{Ca}-\mathrm{SFA}$ and $\mathbf{H F L}=$ high fat level of $50 \% \mathrm{Ca}-\mathrm{SFA}$

$\mathrm{a}, \mathrm{b}$ and $\mathrm{c}$ Means in the same row having different superscripts are significantly different at $\mathrm{P}<0.05$. Daily meat gain $=(($ final live body weight - meat quantaty in carcass $) *$ avearage daily gain $) / 100$ $\mathrm{kg}$ TDMI, TDN and DCP / kg meat yield calculated from (daily meat gain)

Digestibility and Nutritive Values

Nutrient digestibilities and nutritive values of the experimental rations are presented in Table (4). Digestion coefficient of AEE was significantly higher $(\mathrm{P}<0.05)$ with supplemented $\mathrm{Ca}-\mathrm{SFA}$ compared to the unsupplemented one, and also was higher with high level of Ca-SFA. These results are in a good agreement with those obtained by EL-Bedawy et al. (2005), and Aiad et al. (2005) where attributed those results to the high digestibility of added dietary fat. Ruminant animals can digest fats with a high degree of efficiency ranged between $80 \%$ and $90 \%$ for a variety of fatty oils and fatty acids (Moore and Christie, 1984). Palmquist (1984) reported that, calcium soap was solubilized significantly as fatty acids, which increase the solubility of the acid-soap complex in the bile salt. This high efficiency was maintained even when the dietary intake of fatty acids was greatly increased. 
Table 4. Effect of feeding of Ca-SFA on nutrient digestibility, cell wall constituent and nutritive values of the experimental rations

\begin{tabular}{|c|c|c|c|c|}
\hline \multirow{2}{*}{ Item } & \multicolumn{3}{|c|}{ Experimental Rations } & \multirow{2}{*}{$\mathbf{P}<$} \\
\hline & Control & LFL & HFL & \\
\hline \multicolumn{5}{|c|}{ Nutrient digestibility \% : } \\
\hline $\mathrm{DM}$ & $69.04 \pm 0.56$ & $69.91 \pm 0.78$ & $70.04 \pm 2.20$ & ns \\
\hline OM & $71.61 \pm 0.42$ & $72.11 \pm 1.28$ & $71.99 \pm 2.38$ & ns \\
\hline $\mathrm{CP}$ & $56.88 \pm 1.01$ & $57.19 \pm 1.56$ & $57.15 \pm 2.37$ & ns \\
\hline $\mathrm{CF}$ & $66.12 \pm 0.16$ & $66.04 \pm 1.47$ & $65.80 \pm 1.88$ & ns \\
\hline AEE & $68.56 \pm 0.72^{\mathrm{c}}$ & $87.90 \pm 0.92^{\mathrm{b}}$ & $91.57 \pm 0.70^{\mathrm{a}}$ & $*$ \\
\hline NFE & $77.96 \pm 0.49$ & $76.60 \pm 2.99$ & $74.90 \pm 3.98$ & ns \\
\hline $\mathrm{DE}$ & $68.57 \pm 0.33^{b}$ & $72.71 \pm 1.31^{\mathrm{ab}}$ & $75.95 \pm 2.11^{\mathrm{a}}$ & $*$ \\
\hline \multicolumn{5}{|c|}{ Cell wall constituent $\%$ : } \\
\hline $\mathrm{NDF}$ & $64.89 \pm 1.33$ & $61.85 \pm 1.63$ & $61.78 \pm 2.24$ & ns \\
\hline $\mathrm{ADF}$ & $63.08 \pm 1.64$ & $59.04 \pm 2.15$ & $59.07 \pm 2.51$ & ns \\
\hline \multicolumn{5}{|c|}{ Nutritive value $\%$ : } \\
\hline TDN & $66.07 \pm 0.38$ & $68.49 \pm 1.24$ & $69.81 \pm 1.11$ & ns \\
\hline $\mathrm{DCP}$ & $7.37 \pm 0.11$ & $7.49 \pm 0.48$ & $7.06 \pm 0.45$ & ns \\
\hline
\end{tabular}

Digestibilities of $\mathrm{CP}, \mathrm{CF}, \mathrm{NFE}$ and cell wall constituent (NDF, ADF, cellulose and hemi-cellulose) weren't affected significantly $(\mathrm{P}>0.05)$ by supplemented Ca-SFA compared with control group. Weren't affected fiber digestibility could indicated that, added protected fat didn't affect on the cellulotic activity in the rumen. Although adding Ca-SFA improved the energy values of the diets expressed as TDN, but the differences were not significant. The values of DCP didn't significantly differ among the tested groups. The herein results agreed with those obtained by Aiad et al. (2005) and El-Bedawy et al. (2005).

\section{Body dimensions:}

The averages of body dimensions measurement are present of Table (5). Although there are slightly higher values of body dimensions with feeding Ca-SFA diets, there were no significant differences $(\mathrm{P}>0.05)$ among treatments. These findings are in agreement with that reported by (Park et al., 1993) who reported that, plane of nutrition had little effect on hip height and wither, whereas nutritional restrictions on growth involving body length, heart girth and hip width. The values of Body weight (BW), Heart girth (HG), Body length (BL), Highet at withers (HW), Highet at hook $(\mathrm{HH})$, Width at pin bone (WP), Width at hook (WH) and Chest depth (CD) are in agreement with that reported by Sadek (1980). While heart girth (HG), abdominal girth (AG), abdominal height (AH), rump length (RL), width at shoulder (WS) and width at pin bone (WP) are nearest to that obtained by (Khalil, 1981 and Mohi ElDin, 1992) on Egyptian buffalo calves. On the contrary, our results of body weight (BW), heart girth (HG), abdominal depth (AD), abdominal height $(\mathrm{AH})$, highet at withers (HW) and width at shoulder (WS) were higher than those recorded by (Mangurkar and Desai, 1978 ) on Nili-grade she-buffaloes. 
Table 5. Effect of supplementing Ca-FAS on body dimensions (cm)

\begin{tabular}{lcccc}
\hline \multirow{2}{*}{ Item } & \multicolumn{3}{c}{ Experimental Rations } & \multirow{2}{*}{ \pm SE } \\
\cline { 2 - 4 } & Control & LFL & HFL & \\
\hline Body weight (BW) & 351.00 & 357.33 & 359.25 & 19.61 \\
Heart girth (HG) & 202.75 & 209.08 & 206.33 & 10.88 \\
Abdominal girth (AG) & 224.50 & 225.83 & 226.50 & 11.90 \\
Abdominal depth (AD) & 126.42 & 127.00 & 131.33 & 6.92 \\
Abdominal height (AH) & 36.83 & 37.17 & 36.17 & 2.04 \\
Body length (BL) & 148.08 & 157.33 & 157.33 & 8.10 \\
Rump length (RL) & 151.17 & 157.17 & 159.83 & 8.30 \\
Highet at withers (HW) & 76.00 & 80.33 & 82.25 & 4.38 \\
Highet at hook (HH) & 77.17 & 81.00 & 79.08 & 4.19 \\
Width at shoulder (WS) & 76.17 & 77.42 & 78.58 & 4.33 \\
Width at pin bone (WP) & 44.25 & 46.50 & 47.00 & 2.53 \\
Width at hook (WH) & 52.25 & 54.75 & 58.50 & 2.91 \\
Chest depth (CD) & 15.83 & 13.75 & 15.33 & 0.97 \\
General type (GT) & 3.33 & 3.33 & 3.50 & 0.22 \\
\hline Means of 6 animals in each treatment. LFL=low fat level of 25\% Ca-SFA and HFL= high fat level of \\
50\% Ca-SFA & & & \\
a, b, c Means with different superscripts in the same row are significantly difference P<0.05 &
\end{tabular}

\section{Carcass characteristics and average weight of organs:}

The slaughter measurements and carcass evaluation are presented in Tables (6 and 7). Feed rations containing different levels of Ca-SFA didn't significantly affect fasting, empty body weight and carcass weight compared to the control one. Rump round, neck and hot carcass were significantly $(\mathrm{P}<0.05)$ higher with the $50 \%$ level of Ca-SFA compared to the control, while there was no significant difference $(\mathrm{P}>0.05)$ between both levels of Ca-SFA. No significant differences were observed for dressing values between different levels of $\mathrm{Ca}-\mathrm{SFA}$ and the control. Similar response was observed on Egyptian buffalo sire (Sadek, 1980) and on swamp buffalo calves (Shamsudin et al., 1994). Hind right and left quarters were significantly $(\mathrm{P}<0.05)$ higher with $50 \%$ level of Ca-SFA, while no significant differences were found between the level of $25 \% \mathrm{Ca}$-SFA and the control. Adding fat didn't improve fore right and left quarters compared to the control one. Amount of meat for hind and fore right quarter were significantly $(\mathrm{P}<0.05)$ higher with high levels of Ca-SFA compared to low level and the control. Meat of hind left quarter was significantly $(\mathrm{P}<0.05)$ higher with both levels of $\mathrm{Ca}-\mathrm{SFA}$ compared to the control. Adding dietary fat didn't significantly affect the meat of fore lift quarter compared to the control. Protein conversion to gain was better in the fat supplemented group than the unsupplemented one. Dietary fat might a role compensates and save dietary protein (Wu et al., 1993).

The average weight of organs, offals and fat of some organs of finishing buffalo bulls are shown in Table (8). Head, front leg full rumen, empty rumen, lung, spleen, testes, kidney, heart, intestinal fat and skin weight were not affected with feed CaSFA. These results are in agreement with those reported by (Abdallah et al., 1982). Kidney fat and liver weight were significantly higher $(\mathrm{P}<0.05)$ with fed ration containing Ca-SFA than that control ration, except average of liver weight for group received ration containing low Ca-SFA level. 
Table 6. Effect of supplementing Ca-SFA on carcass traits of finishing buffalo bull's diet

\begin{tabular}{|c|c|c|c|c|}
\hline \multirow{2}{*}{ Item } & \multicolumn{3}{|c|}{ Treatments } & \multirow{2}{*}{ $\pm S E$} \\
\hline & Control & $L F L$ & HFL & \\
\hline Fasting body weight, kg & 400.67 & 409.00 & 423.33 & 11.37 \\
\hline Empty body weight, $\mathrm{kg}$ & 349.13 & 359.25 & 374.48 & 12.38 \\
\hline Carcass weight, $\mathrm{kg}$ & 144.33 & 159.00 & 165.00 & 6.91 \\
\hline Rump round, $\mathrm{cm}$ & $71.00^{\mathrm{b}}$ & $77.67^{\mathrm{a}}$ & $78.33^{\mathrm{a}}$ & 1.28 \\
\hline Neck, kg & $8.33^{\mathrm{b}}$ & $9.33^{\mathrm{ab}}$ & $9.67^{\mathrm{a}}$ & 0.33 \\
\hline Hot carcass, $\mathrm{kg}$ & $224.33^{\mathrm{b}}$ & $233.67^{\mathrm{ab}}$ & $248.00^{\mathrm{a}}$ & 5.76 \\
\hline \multicolumn{5}{|l|}{ Dressing (\%): } \\
\hline$\overline{\mathrm{A}}$ & 56.05 & 57.12 & 58.61 & 1.00 \\
\hline B & 64.38 & 65.03 & 66.30 & 1.30 \\
\hline $\mathrm{C}$ & 59.15 & 60.53 & 61.93 & 1.02 \\
\hline $\mathrm{D}$ & 67.93 & 68.91 & 70.05 & 1.34 \\
\hline Fore right quarter & 56.00 & 57.67 & 62.83 & 2.18 \\
\hline Hind right quarter & $55.25^{\mathrm{b}}$ & $58.33^{\mathrm{ab}}$ & $61.17^{\mathrm{a}}$ & 1.47 \\
\hline Fore lift quarter & 57.50 & 58.67 & 62.00 & 1.72 \\
\hline Hind lift quarter & $55.58^{\mathrm{b}}$ & $59.00^{\mathrm{ab}}$ & $62.00^{\mathrm{a}}$ & 1.28 \\
\hline Meat of fore right quarter & $42.00^{\mathrm{b}}$ & $44.50^{\mathrm{b}}$ & $49.50^{\mathrm{a}}$ & 0.91 \\
\hline Meat of hind right quarter & $44.75^{\mathrm{c}}$ & $48.00^{\mathrm{b}}$ & $51.50^{\mathrm{a}}$ & 0.84 \\
\hline Meat of fore lift quarter & 45.50 & 46.33 & 49.50 & 1.28 \\
\hline Meat of hind lift quarter & $45.50^{\mathrm{b}}$ & $51.50^{\mathrm{a}}$ & $54.33^{\mathrm{a}}$ & 1.10 \\
\hline Back fat thickness & 0.39 & 0.40 & 0.41 & \\
\hline \multicolumn{5}{|c|}{$\begin{array}{l}\text { Means of } 3 \text { animals in each treatment. } \mathbf{L F L}=\text { low fat level of } 25 \% \text { Ca-SFA and } \mathbf{H F L}=\text { high fat level of } \\
50 \% \text { Ca-SFA } \\
\text { a, b, c Means with different superscripts in the same row are significantly difference } \mathrm{P}<0.05 . \mathbf{A}=(\text { hot } \\
\text { carcass/fasting body weight }) * 100, \mathbf{B}=\text { (hot carcass/empty body weight }) * 100, \mathbf{C}=[((\text { hot carcass }+(\text { liver } \\
\text { +heart }+ \text { kidney with fat }+ \text { spleen }) / \text { fasting body weight }] * 100 \text { and } \mathbf{D}=[(\text { hot carcass }+(\text { liver }+ \text { heart }+ \text { kidney } \\
\text { with fat }+ \text { spleen }) / \text { empty body weight }]^{*} 100\end{array}$} \\
\hline
\end{tabular}

Table 7. Effect of supplementing Ca-SFA on carcass traits of the finished buffalo bull's diet

\begin{tabular}{lcccc}
\hline \multirow{2}{*}{ Item } & \multicolumn{3}{c}{ Treatments } & \multirow{2}{*}{ \pm SE } \\
\cline { 2 - 4 } & Control & LFL & HFL & \\
\hline Head & 25.25 & 25.75 & 25.00 & 0.35 \\
Tail & $0.50^{\mathrm{b}}$ & $0.80^{\mathrm{a}}$ & $0.80^{\mathrm{a}}$ & 0.06 \\
Hind legs & $5.80^{\mathrm{b}}$ & $6.45^{\mathrm{a}}$ & $6.30^{\mathrm{ab}}$ & 0.18 \\
Front legs & 5.90 & 6.50 & 6.30 & 0.18 \\
Full rumen & 62.00 & 58.33 & 59.00 & 1.81 \\
Empty rumen & 15.60 & 16.05 & 16.45 & 0.34 \\
Lung & 5.50 & 5.70 & 5.85 & 0.19 \\
Liver & $5.85^{\mathrm{b}}$ & $5.65^{\mathrm{b}}$ & $6.30 \mathrm{a}$ & 0.10 \\
Spleen & 0.95 & 1.00 & 0.95 & 0.08 \\
Testes & 0.25 & 0.25 & 0.30 & 0.04 \\
Kidney & 1.25 & 1.35 & 1.25 & 0.09 \\
Heart & 2.25 & 2.65 & 2.25 & 0.13 \\
Kidney fat & $1.85^{\mathrm{b}}$ & $2.95^{\mathrm{a}}$ & $3.00^{\mathrm{a}}$ & 0.10 \\
Intestinal fat & 2.90 & 3.90 & 3.80 & 0.34 \\
Skin weight & 46.50 & 47.00 & 45.50 & 1.03 \\
\hline Means of 3 animals in each treatment. \pm SE: Standard error. LFL=low fat level of $25 \%$ Ca-SFA and HFL= \\
high fat level of 50\% Ca-SFA. a, b, c Means with different superscripts in the same row, differ \\
significantly (P<0.05).
\end{tabular}


Physical and chemical characteristics of Longissimus dorsi muscle

The overall means of physical and chemical traits of longissimus dorsi muscle are reported in Table (8). It was observed that area and depth of longissimus dorsi muscle were significantly higher $(\mathrm{P}<0.05)$ with addition of both level of Ca-SFA compared to the control.

Table 8. Effect of adding fat in bull's rations on physical and chemical characteristic of Longissimus dorsi muscle

\begin{tabular}{|c|c|c|c|c|}
\hline Item & Control & LFL & $H F L$ & $\pm S E$ \\
\hline \multicolumn{5}{|c|}{ Composition of $9,10,11^{\text {th }}$ ribs $(\%)$ : } \\
\hline Lean & 61.42 & 62.25 & 63.12 & 1.10 \\
\hline Fat & $22.48^{\mathrm{b}}$ & $23.65^{\mathrm{a}}$ & $23.66^{\mathrm{a}}$ & 0.27 \\
\hline Bone & 16.10 & 14.10 & 13.22 & 1.22 \\
\hline \multicolumn{5}{|l|}{ Eye muscle traits: } \\
\hline Eye muscle & $56.73^{\mathrm{b}}$ & $61.15^{\mathrm{a}}$ & $61.99^{\mathrm{a}}$ & 1.09 \\
\hline Fat depth over & 0.93 & 0.97 & 0.97 & 0.06 \\
\hline Width of Longissimus dorsi & 15.64 & 16.23 & 16.79 & 0.36 \\
\hline Depth of Longissimus dorsi & $9.22^{\mathrm{b}}$ & $10.13^{\mathrm{a}}$ & $10.35^{\mathrm{a}}$ & 0.22 \\
\hline Index of Longissimus dorsi & 60.42 & 61.69 & 61.88 & 0.43 \\
\hline \multicolumn{5}{|l|}{ Physical characteristics: } \\
\hline $\mathrm{pH}$ & 5.69 & 5.68 & 5.74 & 0.10 \\
\hline Color density & $0.310^{\mathrm{a}}$ & $0.293^{\mathrm{b}}$ & $0.297^{\mathrm{b}}$ & 0.003 \\
\hline Meat tenderness & 3.29 & 3.71 & 3.53 & 0.13 \\
\hline Water holding capacity & 7.20 & 7.21 & 7.21 & 0.11 \\
\hline \multicolumn{5}{|l|}{ Chemical composition (\%): } \\
\hline DM & $25.00^{\mathrm{b}}$ & $28.00^{\mathrm{a}}$ & $29.10^{\mathrm{a}}$ & 0.49 \\
\hline $\mathrm{CP}$ & 76.99 & 78.10 & 78.64 & 1.01 \\
\hline Lipids & 13.25 & 13.33 & 13.67 & 0.35 \\
\hline NFE & 5.74 & 4.87 & 3.79 & 0.96 \\
\hline Ash & 4.00 & 3.70 & 3.90 & 0.15 \\
\hline
\end{tabular}

$\mathbf{L F L}=$ low fat level of $25 \% \mathrm{Ca}-\mathrm{SFA}$ and $\mathbf{H F L}=$ high fat level of $50 \% \mathrm{Ca}$-SFA

Fat content of muscles of 9,10 , and $11^{\text {th }}$ ribs were significantly $(\mathrm{P}<0.05)$ higher with high and low levels of Ca-SFA compared to the control, while no significant differences were found between both levels of Ca-SFA. Carcass measurements such as backfat depth, lean cut percentage and longissimus muscle area were relatively easy to obtain and have been used as general indices of fatness and (or) leanness in cattle (Swatland et al., 1994). Color intensity of fresh muscle was significantly lower $(\mathrm{P}<0.05)$ with both levels of Ca-SFA compared to the control. Several studies on cattle have shown that the bright color associated with oxymyoglobin is retained longer after grass feeding compared with that after grain feeding i.e. shelf life is increased (Wood et al., 2004). No significant different was found when bulls feed diet containing $\mathrm{Ca}-\mathrm{SFA}$ on $\mathrm{pH}$, meat tenderness and water holding capacity. Chemical composition of CP, lipids, NFE and ash for Longissimus dorsi muscle didn't significantly affected with feeding Ca-SFA, while DM was significantly higher $(\mathrm{P}<0.05)$ with feed Ca-SFA compared to the control. These results are within the 
values obtained on buffalo calves by Etman (1985) and Khalifa et al. (2001) and on growing sheep by (Khattab et al., 2003).

The compositions of subcutaneous and longissimus dorsi fatty acids for those finished buffalo bulls are presented in Tables ( 9 and 10). There was a preferential deposition of more unsaturated fatty acids in the subcutaneous adipose tissues in groups feed Ca-SFA compared to the control, and the linoleic acid was the most responsive to diet. When the levels of linoleic acid in the diet have been compared with the resulting depot fat, dietary linoleic acid was found to be preferentially deposited (Dahl and Persson, 1965).

Table 9. Effect of supplementing Ca-SFA on fraction of FA's (\%) of carcass lipid Inter muscular eye muscle (Longissimus dorsi at the $10^{\text {th }}$ rib)

\begin{tabular}{lccc}
\hline \multirow{2}{*}{ Fatty acids profile } & \multicolumn{3}{c}{ Treatments } \\
\cline { 2 - 4 } & Control & LFL & HFL \\
\hline C14:0 & 1.97 & 2.91 & 2.08 \\
C15:0 & 1.02 & 0.92 & 0.87 \\
C16:0 & 30.75 & 26.02 & 25.68 \\
C16:1 & 3.26 & 2.40 & 1.87 \\
C17:0 & 2.79 & 2.13 & 2.54 \\
C18:0 & 15.28 & 14.04 & 14.99 \\
C18:1 & 39.19 & 39.92 & 39.00 \\
C18:2 & 2.53 & 3.86 & 4.95 \\
C18:3 & 1.89 & 4.52 & 4.40 \\
C20:0 & 0.97 & 1.45 & 1.78 \\
C20:1 & 0.35 & 1.83 & 1.84 \\
$\sum$ saturated fatty acids & 52.78 & 47.47 & 47.94 \\
$\sum$ total unsaturated fatty acids & 47.22 & 52.53 & 52.06 \\
$\sum$ mono-unsaturated fatty acids & 42.80 & 44.15 & 42.71 \\
\hline
\end{tabular}

$\mathbf{L F L}=$ low fat level of $25 \% \mathrm{Ca}-\mathrm{SFA}$ and $\mathbf{H F L}=$ high fat level of $50 \% \mathrm{Ca}$-SFA

The degree of unsaturation slightly increased as the level of Ca-SFA in the diet was increased, the greatest increase was found with high content of linoleic acid. These results pointed out that, the fatty acid profile of buffalo bull's adipose tissue reflects that of the diet and feeding Ca-SFA which produced from oils would achieve an ideal (UNS/SA) fatty acid ratio. It appeared from these data that dietary linoleic acid was preferentially deposited in the subcutaneous adipose tissues and longissimus dorsi muscle of the buffalo bulls. Sawosz et al. (1999) reported that feed lecithin and oils rich in n-3 polyunsaturated fatty acids increased $\alpha$-linolenic acid and eicosapentaenoic acid (EPA) in the tissues. At the same time, preliminary studies indicated that conjugated linoleic acid is a powerful anticancer in the rat breast tumor model with an effective range of $0.01-1 \%$ in the diet (Voorrips et al., 2002). Huerta-Leidinz et al. (1991) reported that whole cottonseed in steers diets were raised the linoleic acid level in all depot fats.

Results in Tables (9 and 10) showed that, longissimus dorsi muscle fatty acids contained a higher proportion of saturated fatty acids than those of subcutaneous adipose tissues. The unsaturated fatty acid composition of longissimus dorsi muscle was less than subcutaneous adipose tissues when fed Ca-SFA diet. Comparing results from animals in those groups feed 25 and $50 \%$ levels of Ca-SFA showed that mono- 
unsaturated fatty acid levels didn't differ for subcutaneous adipose tissues and longissimus dorsi muscle.

Table 10. Effect of supplementing growing sheep rations with fat on fraction of FA's (\%) of carcass lipid (Subcutaneous fatty acids in Brisket)

\begin{tabular}{lccc}
\hline \multirow{2}{*}{ Fatty acids profile } & \multicolumn{3}{c}{ Treatments } \\
\cline { 2 - 4 } & Control & LFL & HFL \\
\hline C14:0 & 3.09 & 3.13 & 3.49 \\
C15:0 & 0.86 & 0.82 & 0.95 \\
C16:0 & 30.05 & 25.01 & 23.00 \\
C16:1 & 2.87 & 3.58 & 4.48 \\
C17:0 & 2.31 & 2.22 & 2.22 \\
C18:0 & 13.29 & 12.91 & 13.25 \\
C18:1 & 42.01 & 43.59 & 42.11 \\
C18:2 & 3.61 & 5.02 & 5.87 \\
C18:3 & 1.26 & 3.20 & 4.00 \\
C20:0 & 0.30 & 0.23 & 0.30 \\
C20:1 & 0.35 & 0.29 & 0.33 \\
$\sum$ saturated fatty acids & 49.90 & 44.32 & 43.21 \\
$\sum$ total unsaturated fatty acids & 50.10 & 55.68 & 56.79 \\
$\sum$ mono-unsaturated fatty acids & 45.23 & 47.46 & 46.92 \\
\hline LFL=low fat level of $25 \%$ Ca-SFA and $\mathbf{H F L}=$ high fat level of $50 \%$ Ca-SFA
\end{tabular}

$\mathbf{L F L}=$ low fat level of $25 \% \mathrm{Ca}-\mathrm{SFA}$ and $\mathbf{H F L}=$ high fat level of $50 \% \mathrm{Ca}$-SFA

Correlation coefficients between body weight and some studied traits are included in Table (11). It interesting to note that the correlations between body weight and some traits of body dimensions were high while those between $\mathrm{HC}$ and $\mathrm{AG}, \mathrm{HC}$ and $\mathrm{HW}, \mathrm{HG}$ and AG also HG and HW were poor (Table 11). This indicated that the HG, $\mathrm{AG}, \mathrm{AD}, \mathrm{AH}$ and $\mathrm{HW}$ are better indicators for body weight. Almost all these correlations were highly significant $(\mathrm{P}<0.01)$. These results confirm those reported by Omar (1984), El-Kholy (1991) and Gilbert (1993) on cattle and Salama and Schalles (1991) on water buffalo. At the same time there are high correlations among weight, meat and hot carcass as well as between meat and HC.

The regression equation used for predicting body weight (WP), eye muscle (EMP), hot carcass and values of coefficient of determination for the prediction $\left(\mathrm{r}^{2}\right)$ of WP, EMP and HC are presented in Table (12). Results indicated that the differences in the accuracy of predicting body weight, eye muscle and hot carcass got larger values with WP but was smaller with HC and WP. These results are close to that obtained by Omar (1984), El-Kholy (1991) and Gilbert (1993)

\section{Economics of feeding on Ca-SFA:}

The nutrition cost to produce $1 \mathrm{~kg}$ meat reduced with feeding fat by 12.79 and $12.18 \%$ for $25 \%$ Ca-SFA (LFL) and 50\% Ca-SFA (HFL), respectively, compared with the control ration (Table 13). Revenue, after nutrition cost only, was shown to be higher with feeding Ca-SFA (9.63 and 10.35 LE/h/d for LF and HF, respectively) vs. 8.24 and $4.37 \mathrm{LE} / \mathrm{h} / \mathrm{d}$ for the control ration. These biological and economical results indicate that using Ca-SFA as a source of energy in finishing buffalo bull's rations would improve the revenue and meat production efficiency. 
Table 11. Correlation coefficients among body weight and some traits for body dimensions and carcass characteristics of buffalo fattening bulls feed different levels of Ca-SFA

\begin{tabular}{|c|c|c|c|c|c|}
\hline Traits & HG & AG & AD & $\mathbf{A H}$ & HW \\
\hline \multicolumn{6}{|c|}{ Correlations between body weight and some traits of body dimensions: } \\
\hline Weight & $0.92 * *$ & $0.93 * *$ & $0.89 * *$ & $0.86^{* *}$ & $0.89^{* *}$ \\
\hline $\mathrm{HG}$ & & $0.99 * *$ & $0.96 * *$ & $0.95 * *$ & $0.95 * *$ \\
\hline AG & & & $0.97 * *$ & $0.95 * *$ & $0.94 * *$ \\
\hline $\mathrm{AD}$ & & & & $0.95 * *$ & $0.92 * *$ \\
\hline $\mathrm{AH}$ & & & & & $0.89 * *$ \\
\hline Traits & Meat & $\mathrm{HC}$ & HG & $\mathbf{A G}$ & AD \\
\hline \multicolumn{6}{|c|}{$\begin{array}{l}\text { Correlations between body weight and carcass characteristics with some traits } \\
\text { of body dimensions: }\end{array}$} \\
\hline Weight & $0.69 * *$ & $0.82 * *$ & $0.92 * *$ & $0.92 * *$ & $0.89 * *$ \\
\hline Meat & & $0.86^{* *}$ & $0.39 * *$ & 0.03 & 0.18 \\
\hline $\mathrm{HC}$ & & & 0.24 & 0.10 & 0.18 \\
\hline HG & & & & $0.99 * *$ & $0.96^{* *}$ \\
\hline $\mathrm{AG}$ & & & & & $0.97 * *$ \\
\hline
\end{tabular}

Table 12. Regression equations for predicting weight prediction (WP), eye muscle prediction (EMP) and hot carcass prediction (HCP) using some body dimensions and carcass traits in different experimental groups

\begin{tabular}{|c|c|c|c|}
\hline Regression equation & $\mathbf{R 2}$ & $\mathbf{P}<$ & $\mathbf{C V *}$ \\
\hline \multicolumn{4}{|c|}{ Prediction of body weight from some body dimension traits: } \\
\hline $\mathrm{WP}=15.868 \mathrm{x}+1.650 \mathrm{HG}$ & 0.841 & 0.0001 & 7.511 \\
\hline $\mathrm{WP}=10.598 \mathrm{x}-0.423 \mathrm{HG}+1.917 \mathrm{AG}$ & 0.864 & 0.0001 & 7.038 \\
\hline $\mathrm{WP}=10.737 \mathrm{x}-0.788 \mathrm{HG}+1.958 \mathrm{AG}+0.827 \mathrm{HW}$ & 0.868 & 0.0001 & 7.055 \\
\hline $\mathrm{WP}=11.180 \mathrm{x}-0.499 \mathrm{HG}+2.356 \mathrm{AG}-0.655 \mathrm{AD}$ & 0.868 & 0.0001 & 7.056 \\
\hline $\begin{array}{l}\mathrm{WP}=10.854 \mathrm{x}-0.326 \mathrm{HG}+2.286 \mathrm{AG}-0.432 \mathrm{AD}- \\
1.310 \mathrm{AH}\end{array}$ & 0.869 & 0.0001 & 7.130 \\
\hline $\begin{array}{l}\mathrm{WP}=11.213 \mathrm{x}-0.793 \mathrm{HG}+2.424 \mathrm{AG}-0.615 \mathrm{AD}-0.841 \\
\mathrm{AH}+0.892 \mathrm{HW}\end{array}$ & 0.873 & 0.0001 & 7.143 \\
\hline \multicolumn{4}{|c|}{ Prediction of Eye muscle by body dimension and some carcass traits: } \\
\hline $\mathrm{EMP}=26.858 \mathrm{x}+0.081 \mathrm{FBW}$ & 0.291 & 0.1340 & 4.423 \\
\hline $\mathrm{EMP}=5.883 \mathrm{x}+0.027 \mathrm{FBW}+0.567 \mathrm{RL}$ & 0.756 & 0.0145 & 2.803 \\
\hline $\mathrm{EMP}=7.876 \mathrm{x}+0.0001 \mathrm{FBW}+0.505 \mathrm{RL}+0.059 \mathrm{HC}$ & 0.774 & 0.0453 & 2.954 \\
\hline $\mathrm{EMP}=51.0870 \mathrm{x}+0.221$ fat intake & 0.569 & 0.0188 & 3.448 \\
\hline $\mathrm{EMP}=-63.800 \mathrm{x}+5.042 \mathrm{HC}$ & 0.346 & 0.4117 & 6.967 \\
\hline $\mathrm{EMP}=403.646 \mathrm{x}-2.749 \mathrm{HG}$ & 0.071 & 0.7327 & 9.725 \\
\hline \multicolumn{4}{|l|}{ Prediction of hot carcass by HG or TDN intake: } \\
\hline $\mathrm{HCP}=182.841 \mathrm{x}+0.218 \mathrm{HG}$ & 0.0578 & 0.5734 & 5.937 \\
\hline $\mathrm{HCP}=186.997 \mathrm{x}+9.347 \mathrm{TDNI}$ & 0.1075 & 0.3890 & 5.778 \\
\hline \multicolumn{4}{|l|}{ Prediction of weight by fat intake: } \\
\hline $\mathrm{WP}=0.871 \mathrm{x}+0.004$ fat intake & 0.082 & 0.2501 & 12.847 \\
\hline
\end{tabular}


Table 13. Economical evaluation for using of Ca-SFA in different experimental groups

\begin{tabular}{lccc}
\hline \multirow{2}{*}{ Item } & \multicolumn{3}{c}{ Experimental Rations } \\
\cline { 2 - 4 } & Control & LFL & HFL \\
\hline Feed consumed as fresh $(\mathrm{kg} / \mathrm{h} / \mathrm{d})$ & 8.37 & 8.56 & 8.73 \\
Cost of feed consumed $(\mathrm{LE} / \mathrm{h} / \mathrm{d})$ & 7.18 & 7.29 & 7.20 \\
Price of meat gain $(\mathrm{LE} / \mathrm{h} / \mathrm{d})$ & 15.42 & 16.92 & 17.55 \\
Nutrition cost of $\mathrm{kg}$ meat produced, $(\mathrm{LE})$ & 13.97 & 12.93 & 12.32 \\
Revenue, $(\mathrm{LE})$ & 8.24 & 9.63 & 10.35 \\
\hline LFL $=$ low fat level of $25 \% \mathrm{Ca}$ SFA and $\mathbf{H F L}=$ high fat
\end{tabular}

$\mathbf{L F L}=$ low fat level of $25 \%$ Ca-SFA and $\mathbf{H F L}=$ high fat level of $50 \% \mathrm{Ca}-\mathrm{SFA}$

The price of yellow corn, calcium salts of fatty acids, soybean meal, and cotton seed meal, wheat bran, rice bran, molasses, ground limestone and common salts, were LE 1250, 1650, 1650, 1050, 950, 750, 800, 95 and 120 , respectively.

The price of one ton of berseem hay and rice straw were 750 and 150 L.E, respectively.

Price of meat gain $/ \mathrm{h} / \mathrm{d}, \mathrm{LE}=$ price $\mathrm{kg}$ meat $*$ daily meat gain $($ price of $\mathrm{kg}$ meat $=30 \mathrm{LE}$ )

Revenue, $\mathrm{LE}=$ price of feed consumed $/ \mathrm{h} / \mathrm{d}, \mathrm{LE}$ - Price of meat gain $/ \mathrm{h} / \mathrm{d}, \mathrm{LE}$

Daily increase of meat $/ \mathrm{h} / \mathrm{d} \mathrm{kg}$ See Table (4)

\section{CONCLUSION}

These results indicated that addition Ca-SFA as a source of energy must be taken into account in finishing period of buffalo bulls to improve meat production and quality as well as total revenue.

\section{REFERENCES}

Abdallah, O. Y, S. F. Hussain and G. A. Latif, 1982. Characteristic of mature Egyptian buffalo bulls and cows in relation to meat production: body and carcass composition. Indian J. Anim. Sic. 52:1153.

Abo-Donia, F. M.A., S. A. Ibrahim, H. M. El-Shabrawy and A. M. A. Salama, 2003. Milk production and composition of Friesian crossbred cows fed rations containing different sources of energy. The $9^{\text {th }}$ Scientific Conference on Animal Nutrition, October 2003-Hurghada.P.507.

Aiad, A. M.; H. M. Khattab and F. M. Abo-Donia, 2005. Performance of growing buffalos on diet containing calcium salts of fatty acids. J. Agric. Sci. Mansoura Univ. 30:3559.

Aitken, A., J.C. Casey; I.F. Penny and C.A. Voyls, 1962. Effect of drying temperature on the accelerator freeze drying pork. J. Sci. Food Agric. 13:439

A.O.A.C. 2000. Association of Analytical Chemists. Official Methods of Analysis. International. $17^{\text {th }}$ ed, Vol. .I "Agricultural Chemicals Contaminants, Drug Washington, D.C. USA.

A.O.C.S., 2000. Official and tentative methods of the American oil Chemists Society. Sampling and analysis of soap products. Fatty alkyl sulfates alkyl benzene sulfonates. Section D.

Bauman, D.E., J.W. Perfield, M.J. de Veth, and A.L. Lock, 2003. New perspectives on lipid digestion and metabolism in ruminants. Proc. Cornell Nutr. Conf. pp. 175. 
Byers, F.M., 1982. Nutritional factors affecting growth of muscle and adipose tissue in ruminants. Fed. Proc. 41:2562.

CLFF, 2001. Central Lab for Food and Feed, Feed composition Tables for animal and poultry feedstuffs used in Egypt. P.O. BOX 588 ORMAN, Giza, Egypt. Published by The General Administration of Agrarian Culture.

Dahl, G. and K. Persson, 1965. Properties of animal depot fat in relation to dietary fat. J. Sci. Food Agric. 16:452.

Drackley, J. K.; A. K. Clark and T. Sahlu, 1985. Ration digestibilities and ruminal characteristics in steers fed sunflower seeds with additional calcium. J. Dairy Sci., 68: 386.

Duncan, D.B., 1955. Multiple Ranges and Multiple F test. J. Biometerics, 11:1.

El-Bedawy, T.M., I. A. Gommaa, Sabbah M. Allam and F. M. Abo-Donia, 2005. Production of calcium salts of fatty acids from soap stock on semi industrial scale and its use in finishing rations of Friesian bulls. Egyptian J. Nutrition and Feeds.8:175.

El-Kholy, 1991. Studies on meat production in cattle. Ph.D. Thesis, Faculty of Agriculture, Cairo University.

Etman, K. I., 1985. The effect of limit of concentrate feeding and roughages on meat production. Ph. D. Thesis, Faculty of Agriculture, Moshtoher, Zagazig University.

Gerhardt, Klaus O. and Charles W. Gehrke., 1977. Rapid micro determination of fatty acids in biological materials by gas-liquid chromatography. J. Chromatography 143:335.

Gibney, M.J., 1993. Fish oils in human health. Recent advances in animal nutrition in Australia, D. J. Farrell ed. Univ. of New England, Armidale, NS.W. 2351GIOVANNINI M., RIVAE E., AGOSTONI C. (1998). The role of dietary polyunsaturated fatty acids during the first 2 years of life. Early Hum Dev., 53:99.

Gilbert, R.P., D.R.C. Bailey and N.H. Shannon, 1993. Body Dimensions and Carcass Measurements of Cattle Selected for Postweaning Gain Fed Two Different Diets. J. Anim. Sci. 71:1688

Goering, T. K. and P. J. Vansoest, 1970. Forage fiber analysis, apparatus reagents, procedures and some applications). USD. ARS. Agr. Handbook. No. 379.

Grau, R. And R. Hamm, 1957. Mitteilung bber due bestimmung oler wasser Bindung des Muskels. Zeitschrifs fur laben smittel, untersuchung und forschung, 6:446.

Henderson, L., J. Gregory and. K. Irving, 2003. The national diet and nutrition survey: Adults aged 19-64 years, volume 2: Energy, Protein, Carbohydrate, Fat and Alcohol Intake. London, HMSO.

Huerta-Leidinz, N. O., H. R. Cross, D. K. Lunt, L. S. Pelton, J. W. Savell and S. B. Smith, 1991. Growth, carcass traits, and fatty acid profiles of adipose tissues from steers fed whole cottonseed. J. Anim. Sci. 69:3665.

Hussaini, S.A., F.B. Deartherage and L.E. Kunkle, 1950. Studies on meat. ПObservations on relation of biochemical factors to change in tenderness. Fd. Technol. 4:366.

Jenkins, T. C. and D. L. Palmquist, 1982. Effect of added fat and calcium on in vitro formation of insoluble fatty acid soaps and cell all digestibility, J. Anim. Sci., 55:957.

Khalifa, H. H., M. A. El-Ashry; K. Shahen; N. M. El-Kholi and H. A. Khalifa, 2001. Effect of non-hormonal growth promoters on growth, carcass characteristics and 
body composition of buffalo calves. 1- Effect of yeast culture. Egyptian J. Nutrition and Feeds. 4 (special issue):619.

Khalil, F.F.M., 1981. Studies on animal production" Studies on the meat production of buffaloes". M. Sci. Thesis, Faculty of Agriculture, Mansoura University.

Khattab, H.M., F.A. Salem, M.M. Sayeda and H. M. Nagh, 2003. Effect of Yeasacc, Lacto-sacc supplementations and energy levels on performance, rumen activity, some blood constituents and carcass traits in growing sheep. Egyptian J. Nutrition and Feeds. 6 (special issue):991.

Kim, Y. K., D.J. Schingoethe, D.P. Casper and F.C. Ludens, 1993. supplemental dietary fat from extruded soybeans and calcium soaps of fatty acids for lactating cows. J. Dairy Sci., 76: 197.

Mangurkar, B. R. and R. N. Desai, 1978. Studies on the physical measurements of body size in buffaloes. 1- Genetic and phenotypic. Indian J. Dairy Sci. 31:3.

Mohi El-Din, A. M. (1992). Performance of Egyptian cattle under semi intensive system of production. M. Sci. Thesis, Faculty of Agriculture, Mansoura University.

Moore, W. W. and W. W. Christie, 1984. Digestion absorption and transport of fats in ruminant animals. Page 123 in fats in Animal Nutrition J. Wiseman ed. Butterworth's, London. England.

N.R.C., 2000. Nutrient Requirements of sheep 7th received ED. National Academy pre. Washington. D.C.

Omar, E.A., 1984. Effect of genetic and environmental factors on the growth of male and female calves. M. Sci. Thesis, Faculty of Agriculture, Kafer El-Sheikh, Tanta University.

Palmquisl, D.L., 1984. Use of fats in diets for lactating dairy cows. In: Fats in Animal Nutrition. (Ed. J. Wiseman), Butter worth, pp. 357.

Park, N. H.; M. D. Bishopand and M. E. Davis (1993). Divergent Selection for postweaning feed conversion in Angus beff cattle: Ш. Linear body measurments of progeny. J. Anim. Sci. 71:334.

Sadak, R.R., 1980. Genetic and phenotypic parameters of some productive traits in buffaloes. M. Sci. Thesis, Faculty of Agriculture, Cairo University.

Sainz, R.D., F. De La Torre and J.W. Oltjen, 1995. Compensatory growth and carcass quality in growth-restricted and refed beef Steers1. J. Anim. Sci. 73:2971

Salama, M. A. M. and R. R. Schalles (1991). Growth of water buffalo, bubalus arnee. Trop. Agric. 69:1992.

SAS, 2000. SAS Statistics. Analysis System: SAS User's guide: Inst., Inc., Cary N.C. U.S.A.

Sawosz, E., J. Chachulowa, R. Lechowski and Sz. Fiedorowicz, 1999. Influence of dietary lecithin and oil rich in n-3 polyunsaturated fatty acids (PUSFA) on the fatty acids content of rat muscle and serum. J. Anim. and Feed Scin. 8:485.

Shamsdin, A.B., I.M. Mohd-Shukri, A. Djajanegara and A. Sukmawati, 1994. Effect of feeding Bospro on growth performance and carcass characteristics of swamp buffaloes. Sustainable animal production and the environment, proceeding of the $7^{\text {th }}$ AAAP Animal Sci. Congress, Bali, Indonesia, 11-16 July. 1994. Vol. 2: contributed papers, 367-368. (Abst).

Sukhija, P.S. and D.L. Palmquist, 1988. Dissociation of calcium soaps of long-chain fatty acids in rumen fluid. J. Dairy Sci., 73: 1784. 
Swatland, H. J., S. P. Ananthanarayanan and A.A. Goldenberg, 1994. A review of probes and robots: Implementing new technologies in meat evaluation. J. Anim. Sci. 72: 1475.

Van Keulen, J.V. and B.A. Young, 1977. Evaluation of acid-insoluble ash as a natural marker in ruminant digestibility studies .J. Anim. Sci., 44: 282.

Voorrips, L.E., H.A. Brants, A. F. Kardinaal, G.J. Hiddink and P. van den Brandt, 2002. Intake of conjugated linoleic acid, fat, and other fatty acids in relation to postmenopausal breast cancer: the Netherland cohort study on diet and cancer. Am. J. Clin. Nutr. 76:873.

Wood, J.D., R.I. Richardson; G.R. Nute, A.V. Fisher, M.M. Campo, E. Kasapidou, P. R. Sheard and M. Enser, 2004. Effect of fatty acids on meat quality. A review. Meat Sci. 66:21.

Wu, Z., J.T. Huber, F.T. Sleiman, J.M. Simas, K.H. Chen, S.C. Chan and C. Fontes, 1993. Effect of three supplemental fat sources on lactation and digestion in dairy cows. J. Dairy Sci., 76:3562. 


\section{تأثير تظذيـة مستويات مختلفة مـن الدهن الكالسيومى على المهضوم وأبعـاد الجسم ومواصفات

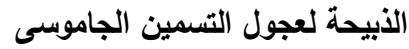 فوزى محمد أبو دنيا، سمير على إبراهيم} معهُ بحوث الإنتاج الحيواني، مركز البحوث الزراعية، الجيزة، مصر تم توزيع 1^ا عجل جاموسى على ثنلاث مجموعات. وتم تكوين ثلاثة أعلاف مركزة بحيث يتم استبدال

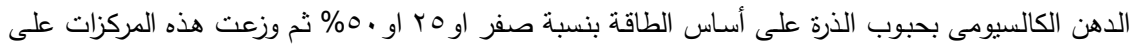

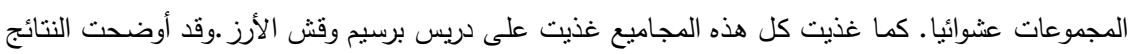

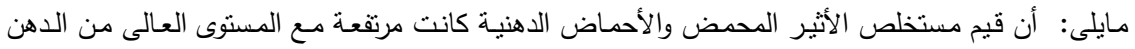

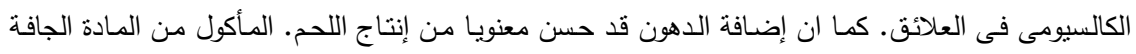

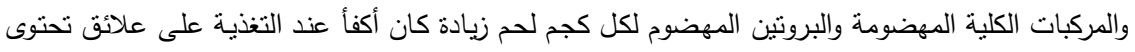

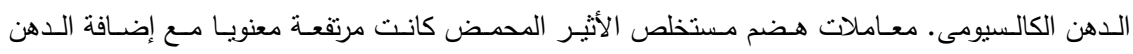

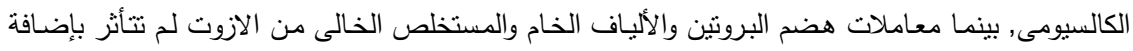

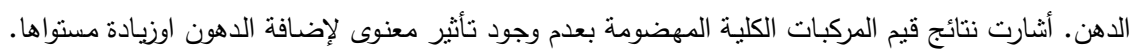

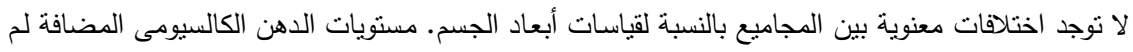

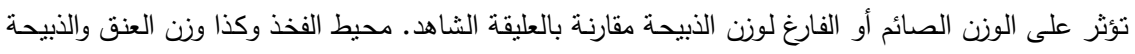

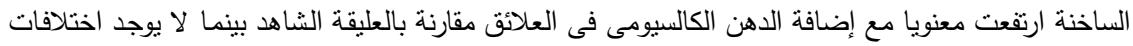

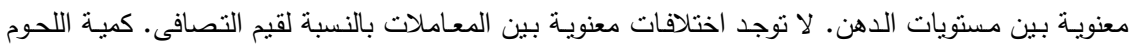

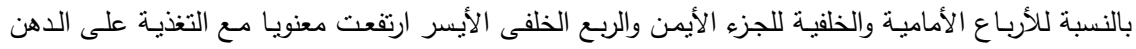

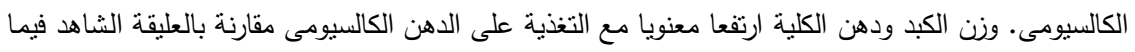
عدا وزن الكبد للمجموعة التى تتاولت مستوى منخفض فى مستوى الدهن الكالسيومى. تركيز اللون ومساحة

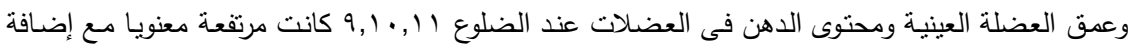

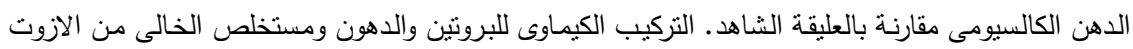

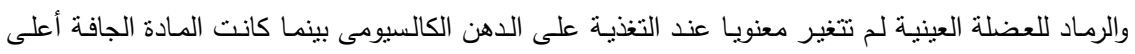

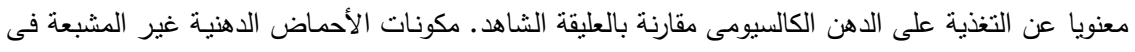

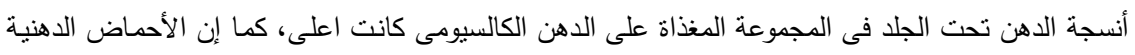

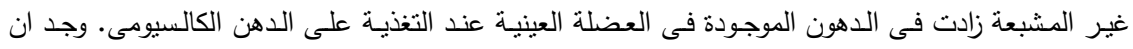

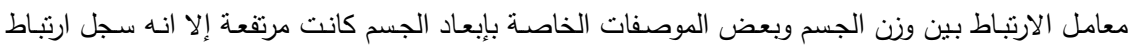

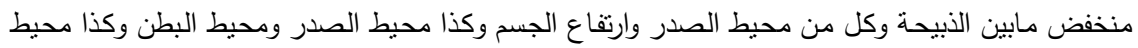

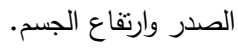
بشكل عام يمكن القول أن إضافة الدهن الكالسيومى فى علائق التهيئة لعجول التسمين الجاموسى من الممكن أن تحسن من جودة اللحوم وزيادة كفاءة إنتاجها. 